\title{
Ženy (a jejich absence) v kyberpunkové SF
}

\author{
Vladimír P. Polách
}

\begin{abstract}
Women (and their Absence) in Cyberpunk SF

The study analyzes the depiction of female characters in the (mostly American) cyberpunk SF. It is based on both the theoretical postulates of the genre that talk about the re-writing of SF literary stereotypes and about social and political radicalism, as well as on the analysis of the primary texts. A critical reading of these texts leads to the (not so surprising) conclusion that the typical cyberpunk hero is a male macho-hero, not a woman with a radically rewritten gender role. This fact brings up a question whether the theoretical premises of cyberpunk have remained unfullfiled or if they were actually directed against the feminist SF of the 70s and 80s. Another part of the study discusses of the definition of a cyberpunk in the sense of the contrast of the "Movement" vs. subgenre.
\end{abstract}

\section{KEYWORDS}

Kyberpunk; gender; Gibson; Sterling; Neuromancer.

\section{KLíčOVÁ SLOVA}

Kyberpunk; gender; Gibson; Sterling; Neuromancer.

\section{Úvodem: SF, kyberpunk a gender}

Science fiction ${ }^{1}$ byla vždy poněkud misogynní, většinou striktně heterosexuální, s ženskými postavami vytlačovanými na okraj. Až na výjimky byly ženy za-

1) K terminologii a označování žánru viz více DĚDINOVÁ 2015: 18-19. Pro tento text používám, bez jakýchkoliv konotací nebo nároků na topologické nuance, označení „science fiction“ synonymně k pojmu „vědeckofantastická li- 
stoupeny asexuálními vědkyněmi, dcerami geniálních vynálezců nebo neštastnými krasavicemi, které mužský über-hrdina zachraňoval ze spárů nepřítele. Pokusy o změnu této stereotypizace přinesla až 60., a především 70. léta 20. století, hlavně v dílech ženských spisovatelek (a částečně i teoretiček), jako je Ursula LeGuinová nebo Joanna Russová. Na začátku 80. let se však zdálo, že SF poměrně stagnuje a spíše recykluje staré motivy i staré osvědčené autory (LEVY 2009: 153).

Kyberpunk, který přichází v polovině 80. let, se od této soudobé SF programově vymezil. Dal si za cíl ukazovat znepokojivé, dystopické, jiné vize budoucnosti. Mohla by mezi tyto jiné vize patřit i re-vize genderových stereotypů platných pro většinu SF literatury? Jak víme, člověk není definován jen a pouze svým biologickým pohlavím, ale také sociální konstrukcí svého genderu, svého postavení, funkce a zařazení ve společnosti. ${ }^{2}$ Velkou roli ve vytváření těchto konstrukcí má také kultura, obzvláště různé formy subkultury, z nichž zrovna SF se svou podstatou jeví jako ideální platforma pro literárně-sociální experimenty (srov. HOLLINGER 1999: 24). Spisovatelka a editorka Pat Cadiganová, se kterou se ještě setkáme, také tvrdí, že „pokud populární kultura je reflexí společenského vývoje [...], platí to dvakrát, ne-li třikrát více o science fiction“ (CADIGAN 2002: x), a Anne Balsamo se přímo zaměřila na kyberpunk, který chápe jako „subkulturu, která se aktivně účastní vytváření kulturních významů“ včetně těch podvratných ve smyslu genderových a jiných stereotypů (BALSAMO 1996: 122).

Cílem této práce je zjistit, do jaké míry se kyberpunková SF snaží opravdu aktivně účastnit vytváření těchto kulturních významů kódovaných jako genderové stereotypy a jaká je jejich re-prezentace nebo re-vize.

teratura“ a zkratkovitému a do jisté míry mezinárodnímu označení „sci-fi“, resp. „SF“. Anglický termín „cyberpunk“ počeštuji jako „kyberpunk“. Názvy literárních děl ale uvádím v anglickém originále, protože u části z nich neexistuje oficiální český překlad. Kde není uveden explicitně autor překladu citací, jde o mé vlastní překlady.

2) Vycházím zde z teorie sociálního učení, genderových stereotypů a genderových schémat, které sice nemusí nutně popírat základní biologické pohlaví, ale kladou velký důraz na vliv společnosti a kultury. Gender se pak ve výsledku projevuje ne jako to „čím jsme, ale spíše tím, co děláme“ (LIPPA 2009: 169), v tomto případě jednak na rovině tvưrčího aktu spisovatele, jednak akceptace a případně i kopírování na straně př́ijemce, čtenáře. Možnostmi alternativního nebo záměrně opozitního čtení textu se z mnoha důvodů v této práci nezabývám. 


\section{K definici kyberpunku}

Kyberpunk představoval v 80. letech 20. století jeden z nejprogresivnějších směrů science fiction. Jeho název pochází ze stejnojmenné povídky Bruce Bethkeho, otištěné v listopadu 1983, a během roku 1984 se stal obecněji známým jednak díky fenomenálnímu úspěchu románu Neuromancer Williama Gibsona, jednak díky průniku do masmédií. Gardner Dozois jej okomentoval v článku Science-Fiction in the Eighties, otištěném na samém sklonku roku ve Washington Post, kde jej charakterizoval jako: „bizzare hard-edged, high-tech stuff“ (DOZOIS 1984). O dva roky později bylo etablování podžánru završeno povídkovou antologií Zrcadlovky, obsahující slavnou Předmluvu z pera Bruce Sterlinga, která se často chápe jako manifest kyberpunku.

Název „kyberpunk“ je ovšem manifestem sám o sobě: „kyber“ odkazuje k funkci kybernetiky, komputerizace a digitalizace; „punk“ k jistému rebelství, boji proti autoritám a vztahu mezi jedincem a společností. Z hlediska motivů a někdy ani narativních postupů nešlo vždy nutně o novátorství, spíše umné využití již starších vzorů. Mezi ty patří klasická díla science-fiction, novátoři a radikálové typu A. Bestera nebo P. K. Dicka nebo psychologizující Nová vlna. Inspirací byla ale i díla mimo oblast SF, především tzv. drsná škola detektivních románů (Hammet, Chandler), postmoderní texty T. Pynchona nebo W. Burroughse nebo subkultura hippies 60. let obecně. ${ }^{3} \mathrm{~V}$ kyberpunku nicméně dochází k jistému posunu. Důraz je ale kladen na všudypřítomnost a všemocnost kybernetiky a technologie vůbec, na proměnu (mnohdy velmi blízké, ne-li současné) společnosti, na ztrátu nebo rozostření jistot a tradic. Role a postavení člověka v této společnosti jsou ohroženy, destabilizovány a proměněny na výrobní hodnoty, což vyvolává odpor. Typickou postavou se stává osamělý hrdina, často počítačový specialista (počítačový kovboj), skrytý za tmavými nebo zrcadlovými brýlemi, stojící osamělý v davu nebo se společenskému kontaktu vyhýbající.

Kyberpunk se také snaží od mainstreamové science fiction odlišit jazykem a estetikou, $v$ některých případech (především u Gibsona) také zhuštěným způsobem narace. Jazyk kyberpunku jednak připomíná profesní slang IT odborníků nebo hackerů, jednak slouží k sociální stratifikaci různých skupin a subkultur, především těch na okraji společnosti. Projev je výrazně zhutněný, postavený na neologismech a útržkovité dialogičnosti, často staví na nedořečenosti, vytržení z kontextu.

3) Mnohé z těchto jmen vyjmenovává již Sterling v Mirrorshades, pro další viz stručně BUTLER 2000: 7-17 a detailněji CAVALLARO 2000: 1-25. 
Estetika kyberpunku se posouvá od tradičního romantizujícího estetična přírody a přirozenosti směrem $\mathrm{k}$ technologii, umělosti a strojovosti (,její krásná tvářička, hladká jako ocel“, „elegantní jako bitevní letoun“). ${ }^{4}$ Příroda jako taková mizí z fikčního světa hrdinů, případně prochází marginalizací nebo destrukcí, výjimečně je ztotožněna s cizostí nebo nebezpečím. Krása samotná je výsledkem kyborgizace lidského těla, nejčastěji v podobě estetické chirurgie. Mnozí autoři pracují se zdánlivým paradoxem estetizace špíny a nedokonalosti, která je výjimečným, charakterizujícím prvkem ve světě, kde peníze, moc a technologie jsou nástrojem k dosažení zdánlivé, někdy ovšem aseptické dokonalosti.

K charakterizaci postav slouží spíše než vykreslení jejich psychologie a motivace jednání jejich jazyk, gesta a oblečení, odkazující ke společenskému zařazení. Čtenář je častěji jen pozorovatelem, vnitřní motivaci postav nezná, nebo se ji dozvídá retrospektivně. Povrchnost, jak říká Hollingerová (HOLLINGER 1991: 212-213), se stává podstatou, aniž by tento princip byl chápán negativně. ${ }^{5}$

Ačkoliv jde o otázku pravděpodobně nepodstatnou z čtenářského hlediska, je pro tuto studii zásadní odlišit kyberpunk jako podžánr SF od kyberpunku jako literárního hnutí, spojeného s úzce vymezenou skupinou autorů. Vhodnou definici kyberpunku nabízí např. Cluteho The Encyclopedia of Science Fiction. Podle ní byla na počátku „škola psaní SF“ a „literární hnutí“, ale po vydání Neuromancera se termín kyberpunk stal natolik populárním, že dal vzniku celému podžánru. ${ }^{6}$ Toto chápání je v souladu s již zmiňovanou Předmluvou k Zrcadlovkám. V tomto ideologickém manifestu Sterling píše, že kyberpunk není jen žánr, ale především hnutî7, skupina autorů. A ačkoliv mluví o „velké vlně spisovatelů“, fakticky vyjmenovává jen pětici, do níž vedle jeho samotného a Gibsona patří ještě Rudy Rucker, John Shirley a Lewis Shiner. Do samotné antologie pak Sterling kromě této „svéc skupiny zahrnul jen pět dalších autorů (Maddox, Kelly, Laidlaw, Bear a di Filippo) a - symptomaticky jen jednu - autorku-ženu, Pat Cardiganovou. Tímto způsobem vytvořil a posvětil okruh kyberpunkových autorů-zakladatelů. Úspěch Neuromancera, Mirrorshades a jiných děl ovšem podnítil i jiné spisovatele a topika i estetika kyberpunku pronikla v 80. letech dokonce i do tvorby veteránů žánru, jako byl Frederik Pohl nebo Poul Anderson (LEVY 2009: 153).

4) Kráceno dle GIBSON 1995: 196, GIBSON 1984: 44.

5) Nejde tedy o autorskou neschopnost nebo ledabylost, ale o záměr. Hollingerová tento narativní princip nechápe kriticky, ale jako logický výsledek Baudrillardovského světa hyperreality, kdy není možné popsat žádné jádro, dokonce ani lidskou podstatu.

6) Clute, J. a kol.: The Encyclopedia of Science Fiction. Heslo Cyberpunk; dostupná z http://www.sf-encyclopedia.com/ entry/cyberpunk, přístup 13. 4. 2018; stejně tak např. LEVY 2009: 155-156.

7) Označení „Hnutí“, tedy „The Movement“, se také často používá jako synonymum kyberpunku v jeho rané fázi, odpovídající právě editorsko-organizačním představám Bruce Sterlinga a Lewise Shinera. 
Paralelně $\mathrm{k}$ tomuto úspěchu se ale objevily první pokusy prohlásit kyberpunk za vyčerpaný, ba dokonce za mrtvý. ${ }^{8}$ Tak už v roce 1986 se William Gibson v rozhovoru s L. McCafferym zmiňuje o tom, že začíná vznikat „špatná imitace kyberpunku“ (GIBSON 2001: 280) a že ve vzduchu je otázka konce kyberpunkového hnutí. Gibson dokonce jako jeden z prvních otevřeně přiznává, že existence tohoto „hnutí“ byla spíše jen otázkou šikovného marketingu (IBID.: 279). O dva roky později se Gregory Benford vyjadřuje ještě jednoznačněji: „[Zrcadlovky] jsou marketingový tah maskovaný za literární hnutí." (CYBERPUNK FORUM 1988: 22).

Ambivalentní byl postoj Bruce Sterlinga. Když 7. ledna 1991 vyšel v literární příloze New York Times esej Confessions of an Ex-Cyberpunk, ve kterém Lewis Shiner prohlásil, že kyberpunk je definitivně mrtvý (SHINER 1991), Sterling na něj reagoval kriticky: ,je to jen dalším pokusem Někoho, kdo-tam-kdysi-byl, prohlásit kyberpunk za mrtvý“ (STERLING 1991). Sám ale uznal, že jde o konec jím původně definovaného hnutí, tento fakt ale nahradil přesvědčením, že kyberpunk se stal nejenom literárním a filmovým mainstreamem, ale vůbec žitou realitou. Jakoby se ale nechtěl vzdát symbolické kontroly nad kyberpunkem, začíná v této době psát o „druhé generaci“ kyberpunkových autorů.

Sterlingovo chápání kyberpunku je nejvíce viditelné z povídkové sbírky The Ultimate Cyberpunk, kterou v roce 2002 připravila Pat Cadiganová. Na okraj podotkněme, že Sterlinga v ní označila za „proroka“ kyberpunku a Zrcadlovky za „průlomovou“ sbírku (IBID.: 398). Vědoma si možných srovnávání obou sbírek, svou vlastní předmluvu nazvala Ne-manifest (Not a Manifesto) a protože nejspíše cítila potřebu kriticky se vyrovnat s velkým množstvím děl, která vznikla v mezidobí mezi oběma antologiemi, požádala Sterlinga, aby to udělal za ni. Vznikl tak seznam nazvaný Představa Bruce Sterlinga o tom, co by měla obsahovat každá dobře vybavená kyberpunková knihovna (STERLING 2002: 383). Vyplývá z něj následující kánon kyberpunku:

1982 - R. Rucker: Software

1984 - W. Gibson: Neuromancer

1985 - B. Sterling: Schismatrix

1985 - G. Bear: Blood Music

1986 - B. Sterling (ed): Mirrorshades

1986 - W. Gibson: Burning Chrome

1986 - W. Gibson: Count Zero

8) Je to klišé přetrvávající dodnes a objevující se i v sekundární literatuře: „Kyberpunk zemřel v roce 1986, pokud ne už dříve“ (BUTLER 2000: 16). 
1987 - P. Cadigan: Mindplayers

1988 - B. Sterling: Islands in the Net

1988 - R. Rucker: Wetware

1988 - W. Gibson: Mona Lisa Overdrive

1989 - B. Sterling: Crystal Express (p)

1989 - J. Shirley: Heatseeker (p)

1989 - L. Shiner: Deserted Cities of the Heart

1990 - Sterling a Gibson: The Difference Engine

1991 - R. Rucker: Transreal! (p)

Je evidentní, že kyberpunk ve Sterlingově pojetí tvořil i v roce 2002 poměrně exkluzivní klub, a v kontextu této práce je signifikantní, že do něj kromě Patricie Cadiganové, často přezdívané královna kyberpunku, nebyla ani šestnáct let po vydání Zrcadlovek zahrnuta žádná jiná autorka-žena.

\section{Genderové čtení kyberpunkových textů}

Kyberpunk se, jak už víme, se v polovině 80. let pasoval do opozice vůči konzervativnímu proudu SF, zahrnující také poměrně stereotypní vykreslování ženských hrdinek. Reagoval tak mimo jiné na nový technologický a společenský kontext. Nástup domácích/osobních počítačů, digitalizace a komunikačních sítí vedla $\mathrm{k}$ radikálním proměnám ve všech sférách lidské činnosti, a v důsledku k úvahám o proměně industriální a post-industriální společnosti ke společnosti „sítové“ a „informační“. ${ }^{9} \mathrm{~V}$ takové mají ženy i muži rovnocenný přístup k informacím, ke komunikačním i výrobním prostředkům, což s sebou přináší také - mimo jiné z čistě ekonomických důvodů - přehodnocování stereotypizace „mužské" a „ženské role“.

Rozvoj výzkumů DNA a nástup genetiky vedly $\mathrm{k}$ obecně přijímané představě lidského těla jako stroje. Toto chápání úzce souvisí s kyborgizací, propojením lidského těla se strojem, možnostmi modifikace a augmentace „nedokonalého" lidského těla, a tím i možnost překonávání jeho biologických limitů. Ruku v ruce s tím jde samozřejmě úvaha o samotné podstatě biologického pohlaví, a především genderové stereotypizace. Potenciál tohoto překonávání popsala v r. 1985 Donna Harrawayová v Manifestu Kyborgů, který se stal jedním

9) Jak je ve svých pracích definují např. F. Webster: Theories of the information society (1995), M. Castells: „trilogie“ Network Society (1996-1998), Jan Van Dijk: The Network Society (1999; orig. 1991). 
z inspiračních zdrojů začínajícího kyberfeminismu a jeho radikálních variant. Pro ty je příznačné překračování ${ }^{10}$ tradičních feministických požadavků rovnosti, otevření otázky volného, na biologickém pohlaví nezávisle konstruovaného genderu a jeho možných „variant“ (transgender, androgynie, kyborgizace, genderová identita umělé inteligence atd.). „Rozšíření technologických úprav ,přirozeného' lidského těla naznačuje, že také [definice] genderu je připravena k rekonstrukci," píše Anne Balsamová (BALSAMO 1995: 216). ${ }^{11}$

Zatímco (eko)feminismus předchozích dekád dával ženský prvek spíše do souvislostí s přírodou, mystičností a psychologií, kyberfeminismus spojuje ženu s počítači a technologiemi. „Ženy a počítače mají jednu věc společnou - totiž že nejsou muži,“" píše Sadie Plantová (PLANT [1993]1997: 503). Podle Plantové byly ženy a přístroje chápány muži na stejné úrovni, jen jako nástroje stvořené k užitku mužů, s nástupem kybernetiky však tato machistická konstrukce zaniká, patriarchát končí. Z historických paralel Plantová dokonce vyvozuje, že ženy mají $\mathrm{k}$ výpočetní technice blíže než muži, že počítač je svým uspořádáním a logikou bližší více ženám (PLANT 1995 ${ }^{12}$ ). Ne vždy je samozřejmě nutné do popisu vytváření genderových rolí zahrnovat prvek hodnocení: genderová role prostě je, má ji každý, nemusí to nutně znamenat, že některá je lepší či vhodnější. ${ }^{13}$

Kyberpunková SF 80 . let se tak zdá být ideálním fikčním prostorem, ve kterém se dá volně spekulovat o proměnách genderu ve společnosti. $\mathrm{K}$ tomuto tvrzení vedou přinejmenším dva důvody. Za prvé již několikrát zmíněná ideologie kyberpunku, která mluví o rozchodu se zatuchlostí současné sci-fi tvorby, s radikalizací, s nástupem nových témat a otázek. „Každý kyberpunk se vyznačuje vizionářskou silou. Jeho autoři oceňují bizarní, fantaskní, dříve nepředstavitelné. Jsou ochotní - dokonce dychtiví - chopit se nápadu a neústupně jej dostrkat až

10) Variant a proudů kyberfeminismu je mnoho a je nutné dodat, že ne všechny interpretují nástup nových technologií pozitivně, jako nástroje osvobození. Naopak, podle mnohých jde jen o nové způsoby zotročení, o posílení mužské dominance, o zneprůhlednění mocenských vztahů apod. Viz např. přehledové, byṫ stručné heslo Cyberfeminism v BELL 2004.

11) Je asi vhodné dodat, že samotná Balsamová dodává, že se tak většinou neděje a různé technologické úpravy nebo změny společenských procesů spíše podporují a utvrzují stávající genderové hranice. Ve své práci se nicméně zabývá potenciálem fikčních světů tyto hranice měnit, přičemž se soustředí na texty P. Cadiganové. U jiných autorů je výsledky spíše skeptická. Cavallaro (CAVALLARO 2000: 75-77) zdůrazňuje, že technologické modifikace lidského těla nemusí vést k požadovanému vylepšení, a to ani u Gibsona nebo Cadiganové.

12) Plantová ukazuje na historickou spojitost „programovatelných“ tkalcovských stavů a jimi inspirovaného analytického stroje Charlese Babbage. Tuto paralelu pak zobecňuje a spojuje tak ženy nejenom s tradičnějším „software“ prvkem, ale přiznává jim i schopnost práce a pochopení pro „hardware“ jakéhokoliv analytického př́istroje.

13) Feministické myšlení, byt’ kritické, většinou vychází z premisy převažující normativní mužské genderové identity, vůči které je ta ženská hodnocena jako vadná. Takto byly často vnímány např. odchylky od „normativního“ mužského chování, mluvených projevů, etiky atd. Srov. RENZETTI - CURRAN 2003: 30-33. 
za krajní mez“ (STERLING 2000: 14). Za druhé explicitně proklamovaná snaha komentovat skrze sci-fi současnou společnost a její stav, nejznáměji komentovaná Gibsonem: „Neuromancer vypráví ve skutečnosti o současnosti, nepopisuje nějakou imaginativní budoucnost. Je to způsob, jakým jsem se vyrovnával s úzkostí a hrůzou, kterou ve mně vyvolal svět, v němž žijeme“ (LEARY 1997: 53).

Tento postoj není cizí ani kritikům a teoretikům kyberpunku. McCaffery chápe kyberpunk jako umění, které se zabývá současnými „politickými, filozofickými, morálními a kulturními otázkami: dalekosáhlými dopady nedávných průlomových objevů v kybernetice, genetickým inženýrstvím, transplantací orgánů, virtuální realitou a [...] společenskými, psychologickými, politickými a behaviorálními změnami vyplývajícími z přechodu od starších industriálních technologií k novějším, informaticko-kybernetickým“14 (MCCAFFERY 1991: 8).

Ještě v polovině 90 . let Douglas Rushkoff, spisovatel i teoretik kyberkultury, popsal vznik tradičního patriarchátu takto: „Lidé žili v kmenech, lovci a sběrači. Byli to nomádi, kteří sledovali stáda zvěře, užívali si volného sexu a uctívali živly. Jakmile se v rámci zemědělské společnosti usadili, všechno se pokazilo. Muži založili patriarchát. [...] Vždy, když muži něčemu nerozuměli, vytvořili si na to schéma, škatulku, se kterou uměli pracovat. [...] Kybernauti dobře ví, že tato schémata, pravidla reality jsou [lidským] výtvorem. Nejsou nutně skutečná." (RUSHKOFF 1994: 169-170). Není důležité, že Rushkoff se plete ve své představě o vzniku a funkci patriarchátu v dějinách, primární je jeho představa o roli „kybernautů“, mezi které lze počítat i autory kyberpunkové SF: oni jsou ti, kdo mají nejenom možnost, ale i povinnost tato schémata rozbíjet.

Tím, že reflektuje současnost, se však kyberpunk nevzdává spekulativnosti v oblasti budoucnosti (mnohé z raných kyberpunkových narativů se odehrávají v opravdu vzdálené nebo neurčené budoucnosti). Zahrnutí modifikací lidského těla i virtuality otvírá opravdu velký prostor ke spekulativnímu uvažování: nemusí jít jen o popis ženských literárních hrdinek, ale také o radikálnější konstrukce - genderová identita kyborgů, umělé inteligence, robotů nebo toho, co přijde po konci tradičního lidství, v době posthumánní. Tu můžeme chápat jednak jako duální život postav ve světě „fyzickém“ a „virtuálním“, jednak jako nemožnost tyto světy vůbec rozlišit. $V$ konečném důsledku pak také ve variantě cíleného přesunu lidské existence z fyzické do virtuální podoby. ${ }^{15}$

14) V podobném textu, který o tři roky dříve otvíral speciální „kyberpunkové“ číslo časopisu Mississippi Review, McCaffery dokonce zdůraznil, že takovým tématům se mainstreamoví autoři nemůžou věnovat. V roce 1991 tento názor zjemnil tím: „mainstreamoví autoři se jen málokdy dostanou k takovýmto tématům“ (srov. McCAFFERY 1988: 9 a McCAFFERY 1991: 9).

15) Veronica Hollinger ukazuje, že i Bruce Sterling dospěl v roce 1985 k představě o konce tradičního „lidství“ 
V následujících kapitolách se pokusím zodpovědět, nakolik jsou tyto premisy naplněny především v kánonu kyberpunkové literatury, jak jej definoval Bruce Sterling. Vycházím přitom z nutně zjednodušené, ale snad přijatelné dichotomie mezi „tradičními“ a "genderově aktualizovanými“ charakteristikami těchto postav. Tradiční genderový stereotyp ženských postav ve sci-fi zahrnuje mj. ženy fyzicky ovládané, dějově pasivní, závislé na mužských postavách a zároveň jimi chráněné nebo ochranu či záchranu potřebující, často ekonomicky nesamostatné, vykreslené jako sexuální, často psychicky labilní objekty nebo estetizované skrze erotické až sexuální prvky a motivy, zastávající tradiční ženská zaměstnání včetně prostituce, ženy jako - primárně - matky a chůvy, ženy ve spojení s přírodou. Pod aktualizací těchto rolí pak nalezneme širokou škálu možností, která se vzpírá jednoduchému výčtu, přináší však změnu vioči výše uvedenému.

\section{Ženské postavy rané tvorby Williama Gibsona}

Postava Molly Millions, poprvé se objevující v povídce Johnny Mnemonic (1981) a rozpracovaná především v Neuromanceru (1984) a v románu Mona Lisa Overdrive (1988 česky vydáno pod názvem Zběsilá jízda; zde vystupuje pod jménem Sally Searsová), se stala archetypem kyberpunkových ženských hrdinek. Její tělo, popisované vágně jako sportovní až atletické, je výrazně modifikované implantáty a operacemi: ikonickými se staly voperované sluneční brýle a zatahovací břitvy. Brýle mají dvojí smysl: navenek odstiňují hrdinku od okolního světa a neumožňují ostatním pohled na její emoce, směrem dovnitř slouží jako technologická extenze zraku, display pro rozšířenou (augmentovanou) realitu. Břitvy, umístěné pod nehty po vzoru „kočičích drápư“, dávají Molly, která se živí jako bodyguard, výhodu v kontaktním boji. Byly přímou inspirací pro termín „Razorgirls“, charakterizující typ literárních i filmových hrdinek (Trinity v trilogii Matrix, Motoko Kusanagi v Ghost in the Shell). Technologická vylepšení fyzického těla dělají z Molly také jednoho z prvních ženských kyborgů.

\footnotetext{
v biologicko-společenském smyslu v románu Schismatrix, „jedné z prvních vědeckofantastických úvah, které se vědomě zaměřuji na vykreslení posthumánních [posthuman] postav a zkoumání implikací z této fráze plynoucích.“ (HOLLINGER 2009: 236). Přechod od duální existence k životu v kyberprostoru je často chápán jako cíl, jako smysl budoucí lidské existence. Na pomezí je interpretace kyberpunku jako popisu situace, kdy se lidské tělo a technologie nedají od sebe odlišit, což vede automaticky ke splývání obou zdánlivě kontradiktorních světů (viz např. HOLLINGER 1991: 205).
} 
Budeme-li postavu Molly interpretovat genderově, pak můžeme konstatovat, že přebírá znaky tradičně spojované s mužskými hrdiny. Je schopná zajistit si vlastní nezávislé postavení, pracuje na základě kontraktu jako ochránce/bodyguard/zloděj atd., je emocionálně poměrně chladná, i v pozdější době žije osamělým životem. Hacker Case, její protipól v Neuromanceru, je v tomto kontextu identifikovatelný jako slabší, submisivní nejenom obecně, ale v kontaktu s Molly i sexuálně, ztracený v reálném prostoru (což si ovšem vynahrazuje v prostoru virtuálním). V postavě Molly vytvořil Gibson novou femme fatale, kopírovanou v následujících letech mnoha jinými autory. Protože jsem se postavou Molly i genderovou interpretací Neuromancera blíže zabýval jinde (POLÁCH 2012), chci zde shrnout jen základní teze.

Molly je ukázkou toho, čeho lze dle Gibsona dosáhnout kyborgizací těla ve spojení s vưlí a tréninkem. Ukazuje možnosti, které technologie ženě nabízí, ovšem za cenu ústupků a obětí. Molly nejenom že přiznává období, kdy se živila „tradiční“ ženskou prostitucí, a byla tedy svým okolím bezohledně vykořistoována, v románu Zběsilá jízda má její postava navíc nádech nenaplněnosti: byl to hacker Case, kdo nakonec založil rodinu a usadil se, zatímco pro ni zbyla jen role stárnoucí nájemné síly a surogátní matky pro dívčí hrdinku tohoto románu, mladou Japonku Kumiko.

V širším kontextu Gibsonova díla je navíc Molly výjimkou, nikoliv standardem. V Neuromanceru kromě ní zastupuje ženské postavy ještě Caseho přítelkyně Linda Lee, která je však využívána spíše k romantické retrospektivě a k rozostřování hranice reálné/virtuální, a zástupkyně bohaté rodiny Tessier-Ashpoolů Lady 3Jane Marie-France. Je vlastně protipólem i doplněním Molly, není ale reprezentant genderové reinterpretace ženské role, spíše reprezentuje jiný Gibsonův topos, totiž odlišnost extrémně bohatých lidí od zbytku světa. ${ }^{16}$

Ostatní ženské postavy v románové trilogii Sprawlu (Neuromancer, 1984, č. 1992; Hrabě nula, 1986; Zběsilá jízda, 1988) nevybočují z genderových stereotypů. V reálném světě nejsou mnohdy schopné se postavit silám, které formují jejich osud. Angela Mitchellová v Hraběti nula je obětí plánů vlastního otce a velkých korporací a autor ji nechává dějem provázet nájemným ochráncem Turnerem (zřejmé otočení rolí vůči Neuromanceru). Ostatní postavy - Marly, Bobby Zero - nijak nepřekračují očekávatelné vzorce chování, které se v případě Bobbyho, hackera a datového kovboje, stávají téměř manýristickými. Stejně tak Mona ze Zběsilé jízdy je loutka, obět systému, po celou dobu strážena nebo

16) Nixonová (NIXON 1992: 225-226) má za to, že 3Jane a její rodina reprezentuje kritiku nejenom extrémního bohatství, ale také útočí na tradiční (americkou) rodinu. 
fyzicky omezována (především, ale ne výlučně) mužskými postavami a není překvapivé, že právě ona je cílem invazivní estetické chirurgie. ${ }^{17}$

Ani povídková sbírka Vypálit Chrom (1986) nepřináší velké množství výrazně „osvobozených“, samostatných a kreativních žen, odhlédneme-li opět od Molly ve povídce Johnny Mnemonic a jen zkratkovitě načrtnutých „Magnetických psích sester“, lesbicko-transsexuálního páru, tamtéž. Nance v Dogfight nejenom že se nemůže sexuálně realizovat kvůli mentální blokaci, kterou jí nechali naprogramovat vlastní rodiče, ale stává se nakonec obětí zoufalého násilí hlavního antihrdiny Dekeho. Rikki v titulní povídce Vypálit Chrom je natolik okouzlena showbussinessem, že investuje své - prostitucí vydělané - peníze do implantátů nových očí a opouští hlavního hrdinu (hrdiny). Sandia v New Rose Hotel je žena-vamp, nástroj velké korporace. Postavy většiny povídek pak nedostávají k genderové analýze dostatek prostoru, případně jsou interpretačně jednoduché.

Výjimečná je Lise z povídky The Winter Market. Její znetvořené tělo, podporované groteskně nedokonalým robotickým exoskeletonem, je protipólem estetické dokonalosti Molly (stejně jako je hlavní hrdina povídky, Casey, parafrází Caseho z Neuromancera). Je to nejspíše jediný Gibsonův text, v němž není technologie vnímána jako estetizující (taktéž HICKS 1996: 82) a kde hlavní hrdinka, toužící uniknout $z$ „klece těla“ do virtuálního světa, si zároveň zoufale uvědomuje biologickou podstatu své existence. Je to také povídka o podstatě kyberpunku, o umění vznikajícím koláží různých fragmentů a o sebehodnocení autora jako umělce nevyhýbajícího se práci s odpadem (HICKS 1996: 79). Vyplývá z ní také výrazný kontrast hodnocení mužského a ženského těla: nedokonalé ženské tělo je přes technologická vylepšení dysfunkční, a tudíž bezcenné; u mužského tato kategorizace chybí.

Fikční svět Gibsonovy tvorby 80 . let je samozřejmě zaplněn mnoha zajímavými ženskými postavami. Jak však naznačují výše uvedené přílady, nelze se ztotožnit s tvrzením Timothy Learyho, že: „Gibsonova definice ženství si také zaslouží obdivný rozbor. Na rozdíl od jeho mužských postav jsou ženy silné, nezávislé, výkonné, hrdinné a působivě atraktivní. Jsou to šamanky, vzdělané čarodějky, hravé, veselé, báječné věštkyně. Gibsonovy ženy mají více světské moci, hmotného know-how, politického zanícení“ (LEARY 1997: 272). Kromě Molly a částečně snad Angelly Mitchellové je ve skutečnosti většina žen Gibsonova fikčního světa vykreslena $z$ pohledu genderu poměrně tradičně.

17) Zajímavá je transformace postavy Angely - Angie - Mitchellové. Na jednu stranu je vykreslená jako produkt showbyznysu (hvězda simulované zábavy, „simstimu“), na straně druhé se Angela stává bohyní kyberprostoru, kam se přesouvají i její kreativní schopnosti. 


\section{Ženské postavy ve zbytku „kánonu“ kyberpunku}

Analyzujeme-li ostatní díla ze Sterlingova „kánonu“ kyberpunku uvedeného výše, dojdeme $\mathrm{k}$ překvapivému zjištění. Téměř v žádném $\mathrm{z}$ nich nevystupuje hlavní, výrazná ženská postava a téměř nikdy není postavena do kontrastu se slabším, submisivním mužem. Laura Websterová ve Sterlingových Islands in the Net je sice v centru celého dění, je to však postava genderově tradiční, manželka a matka, až příliš často odkázaná na pomoc někoho jiného. Rudy Rucker se ve svých textech zabývá sice otázkami lidské sexuality a lidské identity, spíše ale z post-humánního nebo kyborgizujícího hlediska. Lewis Shiner pracuje se ženskou hrdinkou, je však otázka, nakolik je jeho dílo ještě kyberpunkem (odhlédneme-li od umístění ve Sterlingově seznamu), stejně jako „steampunkový“ The Difference Engine autorské dvojice Gibson - Sterling.

Jen Pat Cadiganová, jediná žena zastoupená v tomto seznamu kyberpunkových autorů, vytvořila ve svých textech postavy vymykající se z literárních kyberpunkových (a obecně sci-fistických) klišé, především Alexandru Victorii Haasovou, jinak známou jako Deadpan Allie, kamenná Allie, z Mindplayers. Cadiganová se také jako jedna z mála zamýšlí nad možnou dvojí identitou literárních postav: tou v „reálném“ fikčním světě a tou ve „virtuálním“ fikčním světě. Tento aspekt nalezneme ještě u Gibsona, ale typičtější je pro jeho pozdější knihy, především pro Idoru (1996).

U Cadiganové však nalezneme i ambivalentní postavy. Její Gina z povídky Minutu ticha za rokenrol, obsažené v Zrcadlovkách, je sice na jednu stranu tvưrčí, kreativní „syntetizátorkou“ hudby, nicméně v aktu tvoření je paradoxně pasivní. Scéna, kdy se stává hudebním katalyzátorem skupiny, připomíná pak nejenom erotickou scénu (připojování do datové sítě nebo obecně sdílení dat je v kyberpunku často zobrazováno jako sexuální motiv), ale ze všeho nejvíce scénu hromadného znásilnění. V plejádě ženských postav v Zrcadlovkách pak ale nalezneme mnohem typičtější, tradičnější ženské postavy v podobě Maddoxovy Lizzie $^{18}$ nebo kosmonautky Valentiny z povídky autorské dvojice Gibson - Sterling Rudá hvězda, zimní orbita. ${ }^{19}$

18) Popsaná ve stylu nejhrubších klišé: „Černá sukně rozstřižená na obou stranách až po stehna, k tomu červené punčochy. Na bledé kůži levého ramene měla vytetovanou červvenou růži, od níž obloukem zabíhal zelený stonek mezi nahá ňadra. Políbila ho tak, že mu jazykem vklouzla do úst." Překlad Petr Kotrle.

19) Valentina (Jefremovová?) je s jistým pohrdáním nebo ironií popsaná jako produkt sovětského systému: „Než si ji vybrali pro vesmírný program, byla dělnicí v továrně. S její krásou ji šlo použít jako nástroje propagandy, reprezentanta proletariátu“ (GIBSON - STERLING 2000: 249, překlad Robert Tschorn). 
Zdá se tedy, že spíše než obecně často přijímané klišé o hojně zastoupených silných a výrazných kyberpunkových hrdinkách, které občas rezonuje i v sekundární literatuře (HEREC 2001: 191; CAVALLARO 2000: 121-122), platí kritický výrok G. Benforda: „jedním z pozoruhodných rysů [kyberpunku] je to, jak málo ženy znamenají v kyberpunkovém světě, nejsou-li zrovna chytré ajtačky otrkané městem“ (BENFORD 1988: 22). Podobně N. Nixonová, aniž by se omezovala na Sterlingův seznam kyberpunkových autorů, zjištuje, že v kyberpunku 80. let je „jen velmi málo dalších silných ženských postav“20 (NIXON 1992: 223). Anne Balsamová dochází ve své kritické analýze zobrazování tělesnosti k podobnému závěru: „sexualizace ženského těla je v kyberpunkových povídkách běžným tématem" (BALSAMO 1996: 130).

\section{K možné intepretaci fenoménu ženských kyberpunkových hrdinek}

Krátkou sondu do světa literárních hrdinek ve Sterlingově kyberpunkovém kánonu musíme uzavřít paradoxním zjištěním: navzdory proklamacím o revolučnosti kyberpunku, o jeho společenské angažovanosti, o výletech „za okraj“ a programovému rozchodu s vyčpělou dobovou sci-fi produkcí se ukazuje, že většina ženských postav je vykreslena genderově velmi tradičně. Jsou to krásné, sportovně vypadající femmes fatales, bojovnice v černém koženém oblečení, ženy s bledou pletí a červenou rtěnkou nebo obecně různé reprezentantky romantické, někdy nenaplněné a tragické lásky (přičemž Gibsonova Molly je při jistém úhlu pohledu vším). Jsou často - i když ne vždy - pasivními loutkami v rukou mužů, využívané i zneužívané, živící se nebo donucené k prostituci, sexualizované.

Vysvětlení tohoto paradoxu může být jednoduché. Členové Sterlingova „Hnutí“ jsou typickými reprezentanty bílých, úspěšných, středostavovských mladých mužů, kteří v 80. letech dozrávali a usazovali se. ${ }^{21}$ Část z nich žila v Texasu, spojuje je také kurz kreativního psaní Turkey City Writer's Workshop v texaském Austinu, ideově skupinu formoval především Sterling ve svém kriticky zaměřeném fanzinu Cheap Truth. Jejich tvorbu tak můžeme interpretovat téměř ironicky jako

20) Nixonová vypočítává Gibsonovu Molly, Sarah z Williamsova (poměrně slabého) románu Hardware a Ginu a Allie Cadiganové.

21) Mezi nejstarším Ruckerem (* 1946) a nejmladším Sterlingem (*1954) (sic!) je necelých deset let. Většina z nich v 80 . letech zakládala rodiny a budovala kariéru. 
literární zobrazení v životě nerealizovaných chlapeckých tužeb a romantických představ. ${ }^{22} \mathrm{Na}$ tom samozřejmě není apriori nic špatného, pokusíme-li se ale jejich tvorbu vnímat genderově kriticky, nebo přesněji vztáhnout výsledky této tvorby k proklamovaným programovým prohlášením revolučnosti a novosti, pak je nutné konstatovat, že tento program nebyl naplněn. Ani Gibsonova Molly by nebyla prototypem nově definované ženské genderové role, ale jen literární zobrazením pubertální představy sexuální dominy oblékané v kůži. ${ }^{23}$

Druhý důvod může být komplementární $\mathrm{k}$ tomu prvnímu, je však více programový. O literárních vzorech, ze kterých kyberpunk čerpá, byla již zmínka. Je ovšem evidentní, že mezi vzory, které samotní kyberpunkoví autoři uvádí, téměř vždy chybí vlna feministické a genderově radikální SF 70. a částečně 80 . let. Tyto zdroje inspirace jsou ignorovány dokonce i tam, kde jsou zjevné: v románu The Female Man (1975) Joanny Russové vystupují čtyři ženské hrdinky, z nichž jedna - Jael - se živí jako pouliční zabiják, preferuje černé oblečení, skrývá své emoce a vyznačuje se mimo jiné mechanickými umělými drápy. Je tedy více než pravděpodobné, že Jael (Alice Jael Reasoner) Russové byla předlohou pro Gibsonovu Molly. Shoda neunikla ani dobové kritice, z nichž ta feministická reagovala na mlčení o literárních předlohách odmítavě až vztekle, ${ }^{24}$ ta mužská spíše shovívavě. ${ }^{25}$

Postava Molly není ale jedinou, kterou si Gibson vypůjčuje od feministických autorek 70. let. Jeho Lise v The Winter Market, analyzovaná výše, je parafrází postavy P. Burkeové/Delphi z povídky The Girl Who Was Plugged In z roku 1973, kterou její autorka Alice B. Sheldonová vydala pod pseudonymem James Tiptree Jr., pod nímž publikovala deset let, aniž by její pravá identita byla známá.

Gibsonův vztah k feministicky orientovaným vzorům, i když je třeba nepřiznaný, je ale komplementární, tvůrčí. Pro ostatní autory Sterlingova výběru -

22) Spisovatel Norman Spinrad navrhl v roce 1986 nazývat autory kyberpunku „neuromantiky“ („The Neuromantics“). Tento termín podle něj spojoval nejenom prvky „neuro“ a „nekromancer“, z nichž Gibson udělal název svého zásadního díla, ale přidával k nim také konotaci „nových romantiků“. Podobně Cavallaro (CAVALLARO 2000:130), který pracuje s více variantami („neurotic romancer“) aj.

23) Může jít jen o nesouvisející náhodu, ale ve svém fanzinu Cheap Truth (č. 8; prosinec 1984) popsal Sterling Neuromancera takto: „je dostatečně high-tech na to, aby uspokojil i šestnáctiletého hackera, který trpí na akné, a jehož jediný sexuální život se odvíjí od modemového připojení na diskuzní fórum s XXX obsahem“ (STERLING 1984).

24) První reakcí na toto mlčení byl asi otevřený dopis americké feministické kritičky a literátky J. Gommollové, adresovaný J. Russové. Gommollová v něm reagovala na Sterlingovu Předmluvu k Zrcadlovkám. Dopis byl poprvé vydán v časopisu Aurora, roč. 10, č. 1 (1986-87). Laura Nixonová (NIXON 1992:223) odmítá Gibsonovu Molly jako nevhodnou a neúměrnou feminizaci původní bezohledné Jael, především již zmíněným posunem z Molly do Sally, pečovatelky a náhradní matky ve Zběsilé jízdě.

25) Samuel R. Delany popsal vztah Jael - Molly jako „přetvořeni““ („re-writting“) nebo spíše „poctu“ („hommage“) (CYBERPUNK FORUM 1988: 32). 
samozřejmě s výjimkou Cadiganové - ale spíše platí to, co Sterling přiznal sám o sobě: „Projevoval jsem zvláštní zájem o vzteklé feministické SF traktáty, protože bylo zřejmé, že se ode mě neočekává, že jim budu rozumět" (STERLING 2008: 14, překlad Milan Žáček). Toto neporozumění nebo spíše odmítnutí pak jako vůdčí ideolog kyberpunkového hnutí umně převedl do praxe tím, že poslední dvě dekády vývoje společensky a politicky angažované americké SF ignoroval. Můžeme jít dokonce ještě dále: bylo-li něco v jeho pojetí sci-fi opravdu punkové, bylo to právě toto odmítnutí, tato ignorance, a pokus o návrat ${ }^{26} \mathrm{k}$ modelům hard SF s jejich osamělými, testosteronem nabitými hrdiny. Jak ironicky poznamenala feministická kritička a autorka SF Karen Cadora, kyberpunk se stal „povinně heterosexuálním“ (CADORA 1995: 364).

\section{Závěr: kyberpunk a kyberpunk}

Téměř se vkrádá okřídlená věta, že není kyberpunk jako kyberpunk. Čtenářsky nezajímavé rozlišení mezi původním literárním hnutím, ideově střeženým Bruce Sterlingem, a širší skupinou autorů a autorek tvořících podžánr SF má však svou relevanci v dílčí otázce genderové analýzy.

Carlen Lavigne ve své kritické studii na téma žen ve sci-fi, a především v kyberpunku, došla k velmi kritickému závěru: „ve výsledku je nutné přiznat, že kyberpunk [v otázce ženských hrdinek] nedokázal využít svůj revoluční potenciál“ (LAVIGNE 2013: 17). Toto tvrzení musíme upřesnit: pokud někdo selhal v naplnění předpokladů a potenciálu kyberpunku v této oblasti, pak to byla většina autorů reprezentující prvotní „hnutí“, „první generaci“" ${ }^{27}$ kyberpunkových autorů.

Devadesátá léta - „druhá generace“ - přináší texty, které kyberpunk posouvají dále, k novým vizím, technologiím, diskurzům. Objevují se autoři, kteří staví ženské hrdinky do centra dění (Stephensonův Diamantový věk, pozdní Gibsonovy romány aj.). A přichází řada nových, mnohdy radikálních ženských autorek,

26) Ten lze samozřejmě chápat ironicky a kriticky: zdá se tedy, že tzv. revolučnost kyberpunku se v 80. letech projevila v akcentaci „typického amerického hrdiny“, osamělého jezdce a střelce, kovboje. Nejenom feministické kritičky poukazují na to, že to byl prezident Ronald Reagan, kdo trval na této symboličnosti. Cílem mnoha mužských hrdinů v kyberpunku byl bylo usadit se, mít děti a ranč.

27) V tomto kontextu je dělení na generace zavádějící, protože Sterling zařazuje jednotlivé autory poměrně výběrově, nikoliv přísně chronologicky. Mnozí autoři, kteří začínali psát v 80. letech, navíc pokračovali i v další dekádě atd. Rozlišení na prvotní „hnutí“ a samotný podžánr je přesnější. 
navazující na tradici feministické americké SF. Patři mezi ně na příklad Laura Mixonová (Glass Houses, 1992), Mary Rosenblumová (Chimera, 1993) nebo Karen Cadora, citovaná zde i jako feministická kritička (Stardust Bound, 1994), ale i mnohé jiné. ${ }^{28}$ Tyto autorky otevřely témata jako postavení ženy, rasová nerovnost, vykořist’ování chudoby, otázky maskulinizace/feminizace kyberprostoru, sexualitu robotiky nebo homosexuální hrdiny a hrdinky. Konečně tak naplnily programová prohlášení Bruce Sterlinga a nebály se jít „na krajní mez“.

Přispěvek vznikl za podpory MŠMT, grant IGA_FF_2018_Bohemistika: moderní filologie v 21. století.

\title{
PRAMENY
}

\author{
GIBSON, William \\ 1998 Idoru (Brno: Návrat) \\ 1998 Vypálit Chrom (Brno: Návrat) \\ 1992 Neuromancer (Plzeň: Laser) \\ 1998 Zběsilá jízda (Brno: Návrat) \\ 1997 Hrabě nula (Brno: Návrat)
}

RUSS, Joanna

1977 The Female Man (Boston: Gregg Press)

\section{LITERATURA}

\section{BALSAMO, Anne}

1996 Technologies of the Gendered Body. Reading Cyborg Women (Durham, London: Duke University Press) 1995 „Forms of Technological Embodiment: Reading the Body in Contemporary Culture“, in M. Featherstone, R. Burrows (eds.), Cyberspace/Cyberbodies/Cyberpunk (London: Sage Publications), s. 215-237

BELL, David aj.

2004 Cyberculture. The Key Concepts (London, New York: Routledge)

BUTLER, Andrew M.

2000 Cyberpunk (Harpenden: Pocket Essentials)

CADIGAN, Pat

2002 „Introduction, Not a Manifesto,“ in P. Cadigan (ed.): The Ultimate Cyberpunk (New York: ibooks)

28) K jiným jménům a tématům viz CADORA 1995, LAVIGNE 2013. 
Vladimír P. Polách

Ženy (a jejich absence) v kyberpunkové SF

1987 Mindplayers (New York: Bantam Spectra)

CADORA, Karen

1995 „Feminist Cyberpunk“, Science Fiction Studies, roč. 22, č. 3, s. 357-372

\section{CAVALLARO, Dani}

2000 Cyberpunk and Cyberculture (London, New Brunswick NJ: The Athlone Press)

\section{CYBERPUNK FORUM}

1988 „Cyberpunk Forum/Symposium“, Mississippi Review, roč. 16, č. 2-3, s. 16-65

( DERY, Mark

1996 Escape velocity. Cyberculture at the End of the Century (New York: Groove Press)

\section{DĚDINOVÁ Tereza}

2015 Po divné krajině: charakteristika a vnitřní členění fantastické literatury (Brno: Filozofická fakulta, Masarykova univerzita)

DOZOIS, Gardner

1984 „Science-Fiction in the Eighties“, The Washington Post, 30. 12. 1984

HARAWAY, Donna

1991 „A Cyborg Manifesto: Science, Technology, and Socialist-Feminism in the Late Twentieth Century“ in D. Haraway: Simians, Cyborgs and Women: The Reinvention of Nature (London/New York: Routledge), s. $149-181$

HEREC, Ondrej

2001 Cyberpunk (vstupenka do tretieho tisícročia) (Bratislava: Vydavatel'stvo Spolku slovenských spisovatelov)

HICKS, Heather J.

1996 „,Whatever It Is That She's since Become“: Writing Bodies of Text and Bodies of Women in James Tiptree, Jr.'s „The Girl Who Was Plugged in“ and William Gibson's „The Winter Market“", Contemporary Literature, roč. 37, č. 1, s. 62-93

\section{HOLLINGER, Veronica}

2009 „Posthumanism and Cyborg Theory“, in M. Bould aj. (eds.), The Routledge Companion to Science Fiction (London,New York: Routledge), s. 267-278

1999 „(Re)reading Queerly: Science Fiction, Feminism, and the Defamiliarization of Gender“, Science Fiction Studies, roč. 25, č. 1, s. 23-40

1991 „Cybernetic Deconstructions: Cyberpunk and Postmodernism“, in L. McCaffery (ed.), Storming the reality studio (Durham/London: Duke University Press), s. 203-218

LAVIGNE, Carlen

2013 Cyberpunk Women, Feminism and Science Fiction (Jefferson: McFarland) 
LEARY, Timothy

1997 Chaos a kyberkultura (Praha: Mata/DharmaGaia)

LEVY, Michael

2009 „Fiction, 1980-1992“, in M. Bould aj. (eds.), The Routledge Companion to Science Fiction (London,New York: Routledge), s. 153-162

LÉVY, Pierre

2000 Kyberkultura (Praha: Karolinum)

LIPPA, Richard A.

2009 Pohlaví: př́roda a výchova (Praha: Academia)

McCAFFERY, Larry

1988 „The Desert of the Real: The Cyberpunk Controversy“, Mississippi Review, roč. 16, č. 2-3, s. 7-15

1991 „An interview with William Gibson“, in L. McCaffery (ed.): Storming the reality studio (Durham/London: Duke University Press), s. 263-285

NIXON, Nicola

1992 „Cyberpunk: Preparing the Ground for Revolution or Keeping the Boys Satisfied?", Science Fiction Studies, roč. 19, č. 2, s. 219-235

PLANT, Sadie

1997 „Beyond the Screens: Film, Cyberpunk and Cyberfeminism“, in S. Kemp aj. Squires (eds.), Feminisms (Oxford/New York: Oxford University Press), s. 497-502

1995 „The Future Looms: Weaving Women and Cybernetics“, in M. Featherstone, R. Burrows (eds.), Cyberspace/Cyberbodies/Cyberpunk (London: Sage Publications), s. 45-64

POLÁCH, Vladimír

2012 „Re/de/konstrukce genderových rolí v Gibsonově románu Neuromancer“, in R. Slabáková Švaříčková a kol. (eds.): Re/de/konstrukce genderových rolí v Gibsonově románu Neuromancer (Praha: Nakladatelství Lidové noviny), s. 362-371

RENZETTI, Claire M. - CURRAN, Daniel J.

2003 Ženy, muži a společnost (Praha: Karolinum)

RUSHKOFF, Douglas

1994 Cyberia: Life in the Trenches of Hyperspace (London: Flamingo)

SHINER, Lewis

1991 „Confessions of an Ex-Cyberpunk“, The New York Times, 7. ledna 1991. Dostupné z http://www.fictionliberationfront.net/cyberpunk.html, př́stup 14. 3. 2018 


\section{STERLING, Bruce}

2008 „Předmluva“, in B. Sterling, Vidím to jinak (Praha: Laser-Books), s. 13-19

2000 Zrcadlovky. B. Sterling (ed.) (Praha: Laser-books)

2000 „Předmluva“, in B. Sterling (ed.), Zrcadlovky (Praha: Laser-books), s. 7-15

2002 „Bruce Sterling's Idea of What Every Well-Appointed “Cyberpunk SF” Library Collection Should Posses”, in : P. Cadigan (ed.), The Ultimate Cyberpunk (New York: ibooks), s. 383-389

Mgr. Vladimír P. Polách, M.Phil., Ph.D., vladimir.polach@upol.cz, Katedra bohemistiky, Filozofická fakulta, Univerzita Palackého v Olomouci, Olomouc, Česká republika I Department of Czech Studies, Faculty of Arts, Palacky University, Olomouc, Czech Republic 